\title{
Comparative Studies on Cladophora Glomerata and Chaetomorpha Vieillardi (Cladophoraceae) at North Delta-Egypt
}

\author{
Seham E. Abu Ahmed ${ }^{* 1}$, Mohamed A. Deyab ${ }^{1}$, Radwa S. El-Shanawany ${ }^{1}$ and Magda F. El-Adl ${ }^{1}$ \\ ${ }^{1}$ Department of Botany and Microbiology, Faculty of Science, Damietta University, New Damietta 34517, Egypt
}

Received: 13 December 2020 /Accepted: 10 January 2021

* Corresponding author’s E-mail: Dr_Seham2016@yahoo.com

\begin{abstract}
This study aims to compare between the marine alga Chaetomorpha vieillardi and the freshwater alga Cladophora glomerata. Water samples and massive growth of two species were collected from Port Said marine water pond and Ras El-Bar freshwater pond, respectively in 2019. The highly massive growth of Ch. vieillardi and C. glomerata, due to the trophic status and optimal physicochemical properties of their habitats, causes ecological and economic problems. The very high massive growth of two species leads to relatively complete elimination of dissolved oxygen (DO) at the middle and bottom level of water during the second half of the night. Loss of DO values led to great loss of aquaculture. Although both algal species were belonging to the same family, yet they prefer different habitats where, Ch. vieillardi formed bloom in marine water but $C$. glomerata in freshwater. The significant variation in the biochemical, phytochemical compositions and heavy metal bioaccumulation capacity of Ch. vieillardi and C. glomerata could be attributed to the variation in biological properties of two species and the physicochemical characteristics of their habitats. $C h$. vieillardi has higher carbohydrate and lipid content compared to C. glomerata. Most heavy metals accumulated in $C$. glomerata was more than that in $C h$. vieillardi, but $\mathrm{Cu}$ and $\mathrm{Fe}$ were highly accumulated in Ch. vieillardi.
\end{abstract}

Keywords: Biochemical composition; Chaetomorpha vieillardi; Cladophora glomerata;

physicochemical analysis.

\section{Introduction}

In the north of Egypt, particularly Damietta Province, the environmental conditions of the aquatic ecosystems, are quite suitable for the development of massive algal blooming, thus leading to water pollution and imposing serious threats to the aquatic organisms, quality of water and economic problems. Increasing water turbidity and cyanobacterial blooming have reported to be the causative agents of gastrointestinal illness (Beaudeau et al. 2008). In addition, the continuous discharge of agricultural and domestic effluents into the shallow waters might aggravate the problem through overenrichment with nutrients, in particular nitrogen and phosphorus (Selvi Dhanam et al. 2013).

Filamentous and benthic chlorophyte Harmful Algal Blooms (HABs) can affect directly or indirectly on other biota. Excessive occurrence of algal thalli interferes with the growth of abalone and sea cucumber directly. Decomposing algal mats consume dissolved 
oxygen and result in a hostile physic-chemical environment for marine animals (Chi et al. 2009; Deng et al. 2011a, b). Periodical abundances of this macroalga have a great effect on water quality and sometimes cause great loss of aquaculture (Chi et al. 2009; Deng et al. 2011a, b).

Algae need suitable environmental conditions as temperature, luminous intensity, ultraviolet light, salinity, dissolved gases, nutrients to produce massive growth or blooms (Gressler 2010). These factors promote algae to produce secondary metabolites by processing and converting the primary metabolites of algae (Gressler 2010). These secondary metabolites don't have a direct effect on algal survival, but they play important roles in maintaining natural defense mechanisms by inducing anti-oxidant, anti-viral and anti-microbial activities (Pulz and Gross 2004) to protect algae from changes in the surroundings (Laungsuwon and Chulalaksananukul 2013).

Cladophora glomerata is a filamentous green macroalga with a typically branched thalli (Bellis et al. 1967) . Algae from the genus Cladophora occur both in marine and in freshwater habitat. Cladophora glomerata is a cosmopolitan species mass occurring in Polish inland waters in the form of free-floating mats on the water (Schroeder et al. 2013).

Algae of genus Chaetomorpha are made up of macroscopic filaments of cylindrical cells. The genus is characterized by its unbranched filaments, making it distinctive; its closest relatives are branching species of the genus Cladophora (Choudhury et al. 2005).

Massive growth of Chaetomorpha and Cladophora spp. causes adverse problems, especially when loose algal mats accumulate and decompose. This problem has not been attracting much attention to appropriately benefit from them for human health or avoiding the negative effects on aquatic systems.

So, this study aimed to investigate the massive growth of Chaetomorpha vieillardi and freshwater alga Cladophora glomerata through studying the physicochemical characteristics of their water and their phytochemical, biochemical composition and their heavy metal bioaccumulation capacity.

\section{Materials and Methods}

Sampling collection

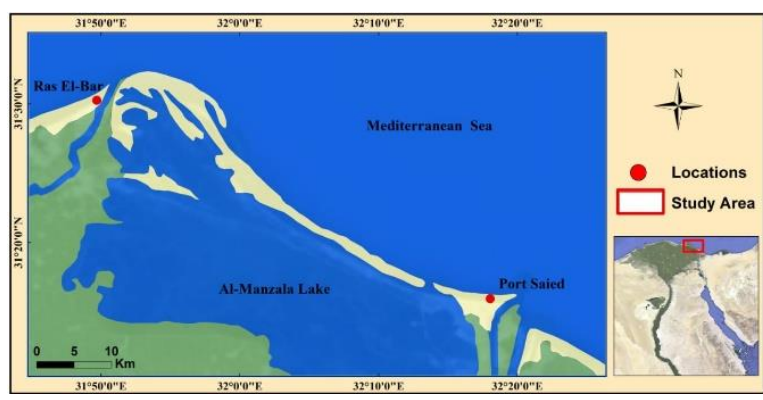

Figure 1: Location map of Mediterranean Sea showing sampling sites

Surface water and algal bloom samples, Cladophora sp and Chaetomorpha sp, were collected manually from a fresh water pond at Ras El-Bar (S1) and marine water pond at Port Said (S2), respectively Fig. 1. Abundance was estimated by placing a quadrate measuring $1 \mathrm{~m}^{2}$ at the sampling points in triplicate. Algal samples within the quadrat were collected and estimated then rinsed well with water to eliminate any adhering substances. These samples were transported to the laboratory in plastic bags under iced conditions as soon as possible.

\section{Preparation of algal samples}

The samples were washed thoroughly with tap water, then with distilled water to get rid of salts and other pollutants. The algal thalli were divided into two parts; a part was stored in $80^{\circ} \mathrm{C}$ for molecular identification and another part was dried in air at room temperature, and then dried in an oven at $80^{\circ} \mathrm{C}$ for $24 \mathrm{~h}$, afterwards it stored until analysis. The algal species were identified ecologically and morphologically according to Aleem (1993) and Coppejans et al. (2009).

\section{Water Physico-chemical properties}

Temperature and $\mathrm{pH}$ of water were determined in situ by using a thermometer and a Horizon (Co 5995) pH meter, respectively. EC and TDS were measured directly using YK-22 CT Conductivity/TDS meter. Phenolphthalein alkalinity (Ph. Ph. Alk) and total alkalinity (T Alk.), dissolved oxygen (DO) every $2 \mathrm{~h}$ for $24 \mathrm{~h}$ along water column (surface, middle and bottom), BOD, $\mathrm{CO}_{2}, \mathrm{COD}$, cations $\left(\mathrm{Ca}^{2+}, \mathrm{Mg}^{2+}\right.$, $\mathrm{K}^{+}, \mathrm{Na}^{+}$and $\left.\mathrm{NH}_{4}{ }^{+}\right)$and anions $\left(\mathrm{NO}_{3}{ }^{-}, \mathrm{NO}_{2}{ }^{-}\right.$, $\mathrm{SO}_{4}{ }^{2-}, \mathrm{Cl}^{-}, \mathrm{HCO}_{3}^{-}, \mathrm{P}_{\mathrm{i}}$ ), TP, TN, EC and total hardness in water were assayed according to APHA (2005). 


\section{Estimation of biological concentration factor $(B C F)$}

Biological concentration factor (BCF) values for algae were calculated using the metal concentration in the organism with respect to dry weight and the total metal concentration in the surrounding water as the following formula. $\mathrm{BCF}$

$=\frac{\text { Metal concentration in the organism }}{\text { Metal concentration in the surrounding water }}$

Estimation of algal biochemical and phytochemical composition

Total soluble sugars (TSS) and total soluble proteins were estimated as described by Schortemeyer et al. (1997) and Bradford (1976), respectively and they were expressed as $\mathrm{mg}$ glucose/protein $\mathrm{g} \mathrm{DW}^{-1}$; glucose/bovine serum albumin was used as the standard material, respectively. The phytochemical screening of different algal extracts was assessed by standard method as described by Savithramma et al. (2011). Lipid was estimated using chloroform: methanol $(2: 1, \mathrm{v} / \mathrm{v})$ as described by Bligh and Dyer (1959).

\section{Statistical analysis}

The data of Physico-chemical properties were subjected to one-way ANOVA using SPSS v 22 at significant level of $p \leq 0.05$.

\section{Results}

\section{Physicochemical properties of water}

The result of water physicochemical properties exhibited a wide-ranging of spatial variations at
S1 compared to S2, where most of Physicochemical properties showed very highly significant variations at $p \leq 0.001$, except $\mathrm{Ph}$. $\mathrm{Ph}$. Alk, T Alk and TN that showed non-significant variations (Table 1). It is noticeable that Port Saied (S2) gave the higher values of water properties compared to Ras El-Bar station (S1), particularly TDS (54.6 to $0.77 \mathrm{~g} / \mathrm{L}), \mathrm{EC}(161.7$ to $1.2 \mathrm{mmhos} / \mathrm{cm}$ ) and $\mathrm{Cl}^{-1}(22$ to $0.14 \mathrm{~g} / \mathrm{L})$, this indicated that $\mathrm{S} 2$ is marine water whereas $\mathrm{S} 1$ is freshwater. However, water $\mathrm{pH}$ values exhibited a wide range of local variation between 7.7 at $\mathrm{S} 1$ and 9.5 at $\mathrm{S} 2$ (at $\mathrm{p} \leq 0.001$ ).

Whereas Temp, DO, BOD, $\mathrm{CO}_{2}, \mathrm{NO}_{2}, \mathrm{PO}_{4}$, $\mathrm{TPO}_{4}$, and $\mathrm{Fe}$, increased significantly by $10 \%$, 6.9 fold, 7 fold, 1.4 fold, 11.5 fold, 12 fold, 4.2 fold, 1.7 fold, respectively at $\mathrm{S} 1$ compared to those at $\mathrm{S} 2$, Temp, DO, BOD, $\mathrm{CO}_{2}, \mathrm{NO}_{2}, \mathrm{PO}_{4}$, $\mathrm{TPO}_{4}$ and $\mathrm{Fe}$ decreased significantly by $9.5 \%$, $87 \%, 87.5 \%, 58 \%, 92 \%, 92 \%, 80.6 \%$ and $63 \%$, respectively at $\mathrm{S} 2$ compared to those at S1(Table 1).

Again, pH, TDS, EC, total Hardness, Ca Hard, $\mathrm{Mg}$ Hard, $\mathrm{Cl}^{-1}$, T Alk., COD, $\mathrm{NH}_{4}, \mathrm{NO}_{3}, \mathrm{Na}^{+}$, $\mathrm{K}^{+}, \mathrm{Ca}^{2+}, \mathrm{Cu}, \mathrm{Co}$ and $\mathrm{Cd}$ increased significantly by $23 \%, 70$ fold, 133 fold, 28 fold, 46 fold, 16 fold, 155 fold, 32 fold, 1.5 fold, $83 \%, 92$ fold, 5 fold, 32 fold, 34\%, 2.4 fold and $88 \%$ in S2 than S1. Conversely, pH, TDS, E.C, T Hardness, Ca. Hard, Mg. Hard, Cl, T Alk., COD, $\mathrm{NH}_{4}, \mathrm{NO}_{3}$, $\mathrm{Na}^{+}, \mathrm{K}^{+}, \mathrm{Ca}^{2+}, \mathrm{Cu}, \mathrm{Co}$ and $\mathrm{Cd}$ decreased significantly by $19 \%, 99 \%, 99 \%, 97 \%, 98 \%$, $94 \%, 99 \%, 38 \%, 97 \%, 60 \%, 45 \%, 99 \%, 84 \%$, $97 \%, 25 \%, 71 \%$ and $47 \%$ in S1 than that at $\mathrm{S} 2$. (Table1). Finally, DO concentration varied between the higher value $\left(8.22 \mathrm{mg} \mathrm{L}^{-1}\right)$ at $\mathrm{S} 1$ and the lower value $\left(4.42 \mathrm{mg} \mathrm{L}^{-1}\right)$ at $\mathrm{S} 2$.

The dissolved oxygen decreases gradually during the second half of the night until complete depletion of DO from water.

Table 1: Physicochemical properties of water samples taken from the study sites. Data are means \pm SE $(n=3)$

\begin{tabular}{|c|c|c|c|}
\hline Parameters & S1 & S2 & $P$ \\
\hline Temperature ( $\mathrm{C}$ ) & $24.67 \pm 0.333$ & $22.33 \pm 0.333$ & $p \leq 0.05$ \\
\hline pH & $7.71 \pm 0.003$ & $9.51 \pm 0.030$ & $p \leq 0.001$ \\
\hline E.C. (mmhos/cm) & $1.21 \pm 0.0007$ & $161.67 \pm 0.882$ & $p \leq 0.001$ \\
\hline TDS (g /L) & $0.772 \pm 0.577$ & $54.60 \pm 0.577$ & $p \leq 0.001$ \\
\hline Salinity (\%) & $3.4 \pm 0.2$ & $38 \pm 0.8$ & $p \leq 0.001$ \\
\hline Chloride (g /L) & $0.14 \pm 0.000$ & $22.11 \pm 0.8$ & $p \leq 0.001$ \\
\hline T Alk. (mg /L) & $160 \pm 0.000$ & $260 \pm 0.000$ & ns \\
\hline Ph.ph. alkalinity & Zero & $120 \pm 0.000$ & ns \\
\hline $\mathrm{CO}_{2}(\mathrm{mg} / \mathrm{L})$ & $126.1 \pm 2.93$ & $52.80 \pm 5.08$ & $p \leq 0.001$ \\
\hline DO $(\mathrm{mg} / \mathrm{L})$ & $8.22 \pm 0.000$ & $4.42 \pm 0.173$ & $p \leq 0.001$ \\
\hline BOD $(\mathrm{mg} / \mathrm{L})$ & $5.42 \pm 0.067$ & $0.677 \pm 0.178$ & $p \leq 0.001$ \\
\hline $\operatorname{COD}(\mathrm{mg} / \mathrm{L})$ & $24 \pm 0.000$ & $800 \pm 0.000$ & $p \leq 0.001$ \\
\hline Ca Hardness (mg/L) & $2.733 \pm 0.035$ & $128.3 \pm 1.67$ & $p \leq 0.001$ \\
\hline Mg Hardness (mg /L) & $4.05 \pm 0.233$ & $66.33 \pm 1.85$ & $p \leq 0.001$ \\
\hline T Hardness (mg /L) & $6.78 \pm 0.194$ & $194.67 \pm 0.333$ & $p \leq 0.001$ \\
\hline
\end{tabular}




\begin{tabular}{lccc} 
Ammonia (mg/L) & $0.914 \pm 0.137$ & $2.28 \pm 0.089$ & $p \leq 0.001$ \\
Nitrite (mg/L) & $0.042 \pm 0.0003$ & $0.003 \pm 0.0007$ & $p \leq 0.001$ \\
Nitrate (mg/L) & $0.954 \pm 0.07$ & $1.74 \pm 0.016$ & $p \leq 0.001$ \\
Organic Nitrogen (mg /L) & $4.350 \pm 0.972$ & $1.400 \pm 0.367$ & $p \leq 0.05$ \\
T N (mg /L) & $6.252 \pm 0.526$ & $5.419 \pm 0.196$ & $n s$ \\
Orthophosphate (mg/L) & $0.048 \pm 0.0007$ & $0.004 \pm 0.0007$ & $p \leq 0.001$ \\
T P (mg) & $0.095 \pm 0.0003$ & $0.018 \pm 0.0009$ & $p \leq 0.001$ \\
Na (mg/L) & $128.055 \pm 2.52$ & $11942 \pm 246.24$ & $p \leq 0.001$ \\
K (mg/L) & $29.66 \pm 0.32$ & $186.71 \pm 2.811$ & $p \leq 0.001$ \\
Ca (mg/L) & $5.798 \pm 0.11$ & $191.30 \pm 1.29$ & $p \leq 0.001$ \\
Fe (mg/L) & $0.29 \pm 0.004$ & $0.11 \pm 0.0006$ & $p \leq 0.001$ \\
Cu (mg/L) & $0.042 \pm 0.0006$ & $0.059 \pm 0.0009$ & $p \leq 0.001$ \\
Co (mg/L) & $0.24 \pm 0.014$ & $0.817 \pm 0.005$ & $p \leq 0.001$ \\
Cd (mg/L) & $0.008 \pm 0.0006$ & $0.015 \pm 0.0006$ & $p \leq 0.001$ \\
\hline
\end{tabular}

Significant $p \leq 0.05$, highly significant $p \leq 0.01$, very high significant $p \leq 0.001$ - ns: non- significant

Table 2: Dissolved oxygen content at different water level during 24h (day and night)

\begin{tabular}{lcccccc}
\hline \multirow{2}{*}{ Time (h) } & \multicolumn{3}{c}{ Normal fresh water } & \multicolumn{3}{c}{ Ras El-Bar freshwater pond } \\
\cline { 2 - 7 } & Surface & Middle & Bottom & Surface & Middle & Bottom \\
\hline $\mathbf{6 - 8}$ & 6.9 & 6.1 & 5.5 & 3.15 & 2.2 & 2.1 \\
$\mathbf{8 - 1 0}$ & 8.1 & 7.2 & 5.6 & 4.3 & 3.5 & 2.1 \\
$\mathbf{1 0 - 1 2}$ & 8.2 & 7.2 & 5.8 & 4.8 & 3.0 & 2.1 \\
$\mathbf{1 2 - 4}$ & & & & & & \\
$\mathbf{1 2 - 1 4}$ & 9.2 & 7.3 & 6 & 5.1 & 2.1 & 1.4 \\
$\mathbf{1 4 - 1 6}$ & 8.1 & 7.4 & 6.2 & 5.1 & 2.5 & 1.3 \\
$\mathbf{1 6 - 1 8}$ & 7.9 & 7.2 & 5.8 & 5.1 & 2.1 & 0.8 \\
$\mathbf{1 8 - 2 0}$ & 7.6 & 6.8 & 5.6 & 4.8 & 1.2 & 0.5 \\
$\mathbf{2 0 - 2 2}$ & 6.9 & 6.4 & 5.1 & 4.8 & 1.2 & 0.3 \\
$\mathbf{2 2 - 2 4}$ & 5.9 & 5.8 & 4.7 & 4.1 & 0.6 & 0.16 \\
$\mathbf{2 4 - 2}$ & 5.5 & 5.1 & 4.5 & 2.13 & 0.18 & 0.08 \\
$\mathbf{2 - 4}$ & 5.2 & 4.8 & 4.3 & 1.9 & 0.10 & 0.01 \\
$\mathbf{4 - 6}$ & 4.9 & 4.6 & 3.9 & 1.18 & & \\
\hline
\end{tabular}

\begin{tabular}{lcccccc}
\hline \multirow{2}{*}{ Time (h) } & \multicolumn{3}{c}{ Normal marine water } & \multicolumn{3}{c}{ Port Saied marine water pond } \\
\cline { 2 - 7 } & Surface & Middle & Bottom & Surface & Middle & Bottom \\
\hline $\mathbf{6 - 8}$ & 6.4 & 5.6 & 4.9 & 5.65 & 4.7 & 4.1 \\
$\mathbf{8 - 1 0}$ & 7.8 & 6.8 & 5.2 & 6.8 & 5 & 4.6 \\
$\mathbf{1 0 - 1 2}$ & 7.6 & 6.8 & 5.4 & 7.3 & 5.1 & 4.7 \\
$\mathbf{1 2 - 4}$ & & & & & & \\
$\mathbf{1 2 - 1 4}$ & 8.4 & 7.1 & 5.8 & 8.8 & 5.6 & 4.8 \\
$\mathbf{1 4 - 1 6}$ & 8 & 7.3 & 6.1 & 9.4 & 6.1 & 5.3 \\
$\mathbf{1 6 - 1 8}$ & 7.8 & 6.9 & 5.6 & 9.9 & 5.8 & 5.0 \\
$\mathbf{1 8 - 2 0}$ & 7.3 & 6.8 & 5.3 & 7.9 & 4.8 & 4.1 \\
$\mathbf{2 0 - 2 2}$ & 6.8 & 5.6 & 4.9 & 6.9 & 3.7 & 3.2 \\
$\mathbf{2 2 - 2 4}$ & 5.8 & 5.13 & 4.5 & 5.9 & 2.5 & 1.5 \\
$\mathbf{2 4 - 2}$ & 5.4 & 4.8 & 4.4 & 4.8 & 1.2 & 0.9 \\
$\mathbf{2 - 4}$ & 5.3 & 4.6 & 4.1 & 3.9 & 0.6 & 0.1 \\
$\mathbf{4 - 6}$ & 4.8 & 4.1 & 3.19 & 2.6 & 0.2 & 0.2 \\
\hline
\end{tabular}

\section{Algal Biochemical Composition}

The starch and lipid $(p \leq 0.05$ and $p \leq 0.001$, respectively) content was significantly higher in Ch. vieillardi than that in C. glomerata by $30 \%$ and $53 \%$, respectively, TSS $(p \leq 0.05)$ content was significantly higher in $C$. glomerata than that in $C h$. vieillardi by $68 \%$. However, protein content was non-significant (comparable) in both C. glomerata and Ch. vieillardi (Table 3). The content of $\mathrm{Fe}(p \leq 0.01), \mathrm{Co}$ and $\mathrm{Cd}$ $(p \leq 0.001)$ significantly increased by $6 \%, 105 \%$ and $83 \%$, respectively in C. glomerata than that in Ch. vieillardi. However, the content of $\mathrm{Na}, \mathrm{K}, \mathrm{Ca}$ and $\mathrm{Cu} \quad(p \leq 0.001)$ increased significantly by 60 fold, 40 fold, 40 fold and 4 fold respectively, in $C h$. vieillardi than that in C. glomerata (Table 3). 
Table 3: Biochemical composition of C. glomerata and Ch. vieillardi and BAF, Data are means $\pm \mathrm{SE}(\mathrm{n}=3)$

\begin{tabular}{|c|c|c|c|}
\hline Parameters & C. glomerata & Ch. vieillardi & $P$ \\
\hline Protein ( mg g DW' $\left.{ }^{-1}\right)$ & $6.66 \pm 0.45$ & $7.50 \pm 0.54$ & $\mathrm{~ns}$ \\
\hline TSS ( mg g DW $\left.\mathbf{D W}^{-1}\right)$ & $15.45 \pm 1.27$ & $9.18 \pm 0.90$ & $p \leq 0.05$ \\
\hline Starch $\left(\mathbf{m g ~ g ~ D W} \mathbf{W}^{-1}\right)$ & $38.97 \pm 1.78$ & $50.65 \pm 4.6$ & $p \leq 0.05$ \\
\hline Lipids (mg g DW ${ }^{-1}$ ) & $19.00 \pm 0.06$ & $29.00 \pm 0.06$ & $p \leq 0.001$ \\
\hline $\mathrm{Na}\left(\mathrm{mg} \mathrm{g} \mathrm{DW}^{-1}\right)$ & $0.15 \pm 0.013$ & $9.103 \pm 0.14$ & $p \leq 0.001$ \\
\hline $\mathrm{K}\left(\mathrm{mg} \mathrm{g} \mathrm{DW} \mathbf{D W}^{-1}\right)$ & $0.495 \pm 0.02$ & $20.43 \pm 0.17$ & $p \leq 0.001$ \\
\hline Ca $\left(\mathrm{mg} \mathrm{g} \mathrm{DW}^{-1}\right)$ & $0.23 \pm 0.009$ & $9.39 \pm 0.062$ & $p \leq 0.001$ \\
\hline Fe $\left(\mathrm{mg} g \mathrm{DW}^{-1}\right)$ & $1.18 \pm 0.006$ & $1.11 \pm 0.003$ & $p \leq 0.01$ \\
\hline $\mathrm{Cu}\left(\mathrm{mg} \mathrm{g} \mathrm{DW}^{-1}\right)$ & $0.055 \pm 0.0009$ & $0.277 \pm 0.003$ & $p \leq 0.001$ \\
\hline Co $\left(\operatorname{mgg} D^{-1}\right)$ & $3.54 \pm 0.067$ & $1.73 \pm 0.032$ & $p \leq 0.001$ \\
\hline Cd (mg g DW $\left.{ }^{-1}\right)$ & $0.19 \pm 0.004$ & $0.10 \pm 0.00$ & $p \leq 0.001$ \\
\hline $\mathrm{BCF}(\mathrm{Fe})$ & 4.13 & 10.50 & \\
\hline BCF $(\mathrm{Cu})$ & 1.33 & 4.93 & \\
\hline BCF (Co) & 14.92 & 2.12 & \\
\hline BCF (Cd) & 24.24 & 6.98 & \\
\hline
\end{tabular}

\section{Biological concentration factor $(\mathrm{BCF})$}

Ch. vieillardi accumulates $\mathrm{Fe}, \mathrm{Cu}, \mathrm{Co}$ and $\mathrm{Cd}$ in its cells by approximately 11 fold 5 folds, 2 folds and 7 fold, respectively more than that in seawater versus to approximately 4 folds, 1.3 folds, 15 fold and 24 folds, respectively in $C$. glomerata (Table 3). The calculated BCF exhibited that $C h$. vieillardi uptakes metals in the order of $\mathrm{Fe} \square \mathrm{Cd} \square \mathrm{Cu} \square$ Co compared to $\mathrm{Cd} \square \mathrm{Co} \square \mathrm{Fe} \square \mathrm{Cu}$ in C. glomerata.

\section{Phytochemical composition}

The results showed remarkable variations in the type and concentration of phytochemical compound between $C h$. vieillardi and $C$. glomerata (Table 4). Whereas tannins, phenols and quinones are absent in both $C h$. vieillardi and $C$. glomerata, yet flavonoids and coumarins are equivalent in both them. While saponins are present in C. glomerata, but not in Ch. Vieillardi, glycosides are present in $C h$. vieillardi, but not in C. glomerata. Terpenoids and steroids were higher in $C$. glomerata compared to $C h$. vieillardi. On the contrary, alkaloids were lower in $C$. glomerata compared to Ch. vieillardi.

Table 4. Qualitative analysis of phytochemical substances in C. glomerata and Ch. vieillardi

\begin{tabular}{clcc}
\hline & Test & C. glomerata & $\begin{array}{c}\text { Ch. } \\
\text { vieillardi }\end{array}$ \\
\hline 1. & Alkaloids & + & ++ \\
2. & Terpenoids & ++ & + \\
3. & Steroids & ++ & + \\
4. & Tannins & - & - \\
5. & Saponins & + & - \\
6. & Flavenoids & + & +
\end{tabular}

\begin{tabular}{rlrc} 
7. & Phenols & - & - \\
8. & Coumarins & + & + \\
9. & Quinones & - & - \\
10. & Glycosides & - & + \\
\hline
\end{tabular}

\section{Discussion}

Physico-chemical properties of water

The significant variation in Physico-chemical properties of water confirmed that $C$. glomerata inhabits freshwater whereas $C h$. vieillardi prefers to inhabit marine water. This agree with the results of Tsutsui et al. (2015) who reported that Chaetomorpha inhabits salinities of $3.4-90.0 \%$. The freshwater $\mathrm{pH}$ value (7.7) maybe suitable to the excessive growth of $C$. glomerata according to the study range of Messyasz et al. (2015) who reported that $\mathrm{pH}$ range for Cladophora massive development ranged between 7.8 and 8.3. In addition Xu et al. (2009) confirmed that the growth of Ch. valida increased with increasing the range of $\mathrm{pH}$ from 6.5 to 8.5 . Also, the growth and photosynthetic activity of algae are closely tied to the temperature, $\mathrm{pH}$, salinity, and other environmental factors (Fu 2014).

The high concentration of DO at S1 $\left(8.22 \mathrm{mg} \mathrm{L}^{-}\right.$ $\left.{ }^{1}\right)$ could be attributed to the high content of $\mathrm{Chl}$ $a$ (Smith and Piedrahita 1988) of $C$. glomerata bloom, besides, Increasing the solar radiation that is favorable for photosynthesis, increase the DO concentration producing from algal blooms during the day (Sánchez et al. 2007), this indicates that $C$. glomerata could favor clean freshwater (ultra-oligotrophic) at Ras El-Bar freshwater pond. Whereas the lower 
DO concentration at $\mathrm{S} 2\left(4.42 \mathrm{mg} \mathrm{L}^{-1}\right)$, even though massive growth of Ch. vieillardi, may be due to the decrease in oxygen solubility with increasing salinity (Mountford 1969), this signifies that $C h$. vieillardi could prefer polluted saline water (hyper-eutrophic status). Since the insufficient dissolved oxygen $(<2 \mathrm{mg}$ $\left.\mathrm{L}^{-1}\right)$ will occur at very low or very high concentrations of Chl a (Smith and Piedrahita 1988), therefore, water quality and trophic status were ranged between moderate pollution (mesotrophic) at S1 and very polluted water (hyper-eutrophic) at $\mathrm{S} 2$.

The high values of BOD and considerable values of $\mathrm{COD}$ at $\mathrm{S} 1$ compared to $\mathrm{S} 2$ may be attributed to the increase of photosynthetic organisms that produce an additional oxygen during the decomposition of dead biomass (Sánchez et al. 2007). Whereas the very high values of COD at $\mathrm{S} 2$ probably due to the relative high water pollution and the oxidative of the organic matter (pollutants and dead algal biomass). These leads to the reduction of dissolved oxygen concentration and the increase in oxygen deficit (Sánchez et $\boldsymbol{a l}$. 2007). Furthermore, BOD/COD ratio at $S 1$ (Ras El-Bar fresh water pond) equals 0.22 versus to 0.0009 at $\mathrm{S} 2$ (Port Saied marine water pond), this signifies that Damietta Ras El-Bar fresh water is in a biodegradable range (between 0.1 and 1.0) as described by Samudro and Mangkoedihardjo (2010). However, the decreased ratio of BOD/COD at Port Saied marine water pond could be attributed to high water pollution and high salinity of seawater (Mehrdadi et al. 2006).

The present studies revealed that the dissolved oxygen content at study area decreased gradually during night toward bottom. Moreover, the DO at middle and bottom level of water recorded very low values or relatively depletion. These mainly due to the stop production of DO at the second half of night and in the same time, the consumption of DO through BOD and COD continued. Consequently, the DO of water decreased to very low level (relatively zero) (Kibria 2004). The decreased of DO at two water ponds which containing massive growth of Cladophora and Chaetomorpha resulting in high loss of aquatic aquacultures production (Fish production) (Boyd and Hanson 2015).

The significant increase in $\mathrm{NO}_{2}$, Organic $\mathrm{N}, \mathrm{TN}$ and $\mathrm{TP}$ concentrations and decrease in $\mathrm{NH}_{4}$ and
$\mathrm{NO}_{3}$ in $\mathrm{S} 1$ may be attributed to that some $\mathrm{NH}_{4}-$ $\mathrm{N}$ and $\mathrm{NO}_{3}$ could be incorporated into organic nitrogen by the algae, increasing $\mathrm{TN}$ where $\mathrm{N}$ within the dead algae cannot be dissolved back into the water completely without the denitrification process ( $\mathbf{L i}$ et al. 1991). The ratio of $\mathrm{N}: \mathrm{P}$ at $\mathrm{S} 1$ and $\mathrm{S} 2$ were $(66: 1$ and $300: 1$, respectively) more than the optimum $\mathrm{N}$ : $\mathrm{P}$ ratio which is favorable to the algae growth and their uptake of $\mathrm{P}$ according to Li et al. (1991) who reported that the optimum ratio of $\mathrm{N}$ : $\mathrm{P}$ is 5:1.

The decrease in $\mathrm{P}$ concentration that concomitant with increased $\mathrm{pH}$ at $\mathrm{S} 2$ compared to $\mathrm{S} 1$ could be attributed to the algal photosynthesis increases $\mathrm{pH}$ that promotes the removal of $\mathrm{P}$ through precipitation. Although algae can use organic and inorganic $\mathrm{P}$, they mainly depend on inorganic $\mathrm{P}$ and convert it into organic $\mathrm{P}$ for themselves, which will be partly released back to the surrounding water and then settle to the bottom of the aquatic system when they die (Li et al. 1991).

The significant increase in TSS content and decrease in starch and lipid content of freshwater $C$. glomerata compared to marine Ch. vieillardi could be attributed to water salinity effect (Chaves and Oliveira 2004). This suggests that Ch. vieillardi could be a source of biodiesel production as well as carbohydrate. Meanwhile, the higher content of $\mathrm{Na}, \mathrm{K}$ and $\mathrm{Ca}$ in $C h$. vieillardi compared to $C$. glomerata could be attributed to that $C h$. vieillardi has the ability to accumulate essential mineral elements (Aziza et al. 2014).

The higher content of $\mathrm{Fe}, \mathrm{Co}$ and $\mathrm{Cd}$ in $C$. glomerata compared to $C h$. vieillardi, the reverse was true for $\mathrm{Cu}$. This suggests that freshwater $C$. glomerata has the ability to accumulate high content of heavy metals more than marine $C h$. vieillardi. This partially agrees with the findings of Aziza et al. (2014) who reported that algae have the ability to accumulate heavy metals. The significant difference in physicochemical characteristics of habitats might be responsible for the variance in chemical composition of $\mathrm{Ch}$. vieillardi compared to $C$. glomerata.

\section{Heavy metals and BCF}

The increased BCF values in C. glomerata and Ch. vieillardi with decreasing metal concentration in the surrounding medium could be attributed to that $C$. glomerata and $C h$. 
vieillardi cells have high negative surface charge that attract heavy metal cations (Rao et al. 1986). Ch. vieillardi effectively accumulates $\mathrm{Fe}$ and $\mathrm{Cu}$ versus $\mathrm{Co}$ and $\mathrm{Cd}$ in C. glomerata. This means that the heavy metal accumulation from the surrounding medium did not equal for all organisms and for all metals (Canterford $\boldsymbol{e t}$ al. 1978). This suggests that the selectivity of heavy metals accumulation in C. glomerata or Ch. vieillardi could be used as a means of removing metals from heavy metal polluted water and industrial effluents. The decrease of heavy metal concentration in Ras El-Bar freshwater compared to marine water could be attributed to that Cladophora is an ancient biosorbent of some heavy metals (Lee and Chang 2011), because the polysaccharides with ion-exchange properties in its cell wall can bind with heavy metals (Żbikowski et al. 2007). Therefore, C. glomerata could be the most proper bio-indicator of heavy metals in aquatic bodies (Borowitzka and Borowitzka 1988).

\section{Conclusion}

The dissolved oxygen content at study area decreased gradually during night toward bottom. Moreover, the DO at middle and bottom level of water recorded very low values or relatively depletion. The decreased of DO at two water ponds which containing massive growth of Cladophora and Chaetomorpha resulting in high loss of aquatic aquacultures production. The variance of $C h$. vieillardiand $C$. glomerata phytochemical and biochemical composition could be attributed to the difference in the physicochemical properties of their habitats. Ch. vieillardi has higher carbohydrate and lipid content compared to $C$. glomerata. Meanwhile heavy metal concentration in freshwater was more than that in marine water except $\mathrm{Cu}$, yet $\mathrm{Fe}$ and $\mathrm{Cu}$ were highly accumulated by marine $C h$. vieillardi versus $\mathrm{Cd}$ and $\mathrm{Co}$ by freshwater $C$. glomerata.

\section{Acknowledgement:}

The authors express their thanks to the laboratory of algae at Botany and Microbiology Department at Damietta University.
Aleem AA (1993) The Marine Algae of Alexandria. Egypt. Egyptian Books House.

American Public Health Association (APHA) (2005) Standard Methods for the Examination of Water and Wastewater, $21^{\text {st }}$ edition.

Aziza M, Laila B, Vincent G, Ahlam M, Hakima Z and Thierry G (2014) Accumulation of heavy metals by macroalgae along the Atlantic coast of Morocco between El Jadida and Essaouira. World Journal of Biological Research 6 (1): 1-9.

Beaudeau P, Schwartz J, Levin R (2008) Drinking water quality and hospital admissions of elderly people for gastrointestinal illness in Eastern Massachusetts. Water Res 52: 188-198.

Bellis VJ, McLarty DA (1967) Ecology of Cladophora glomerata (L.) Kütz. in southern Ontario. Journal of Phycology, 3, 57-63.

Bligh EG, Dryer WJ (1959) A rapid method of total lipid extraction and purification. Can J Biochem physiol, 37: 911-7.

Borowitzka MA, Borowitzka LJ (1988) Micro-algal biotechnology. Cambridge University Press. New York, NY, USA 477 pp

Boyd CE and Hanson T (2015) Dissolved Oxygen Concentration in pond aquaculture. Global aquaculture advocate, 40-41.

Bradford MM (1976) A Rapid and Sensitive Method for The Quantification of Microgram Quantities of Protein Utilizing The Principle of Protein Dye Binding. Analytical Biochemistry, 72: 248-54.

Canterford G, Buchanan A, Ducker S (1978) Accumulation of heavy metals by marine Dithylum brightwelli (west) Grunow. Aust. J. Freshwat.Res. 29: $613-622$

Chaves MM, Oliveira MM (2004) Mechanisms underlying plant resilience to water deficits: prospects for water-saving agriculture. Journal of experimental botany, 55(407), 2365-2384.

Choudhury S, Sree A, Mukherjee SC, Pattnaik P, Bapuji M (2005) In vitro antibacterial activity of extracts of selected marine algae and mangroves against fish pathogens. Asian Fisheries Science; 18(3/4):285-294.

Chi YX, Wang LM, Luan RX, Wang HW (2009) Chaetomorpha valida, a new recorded green alga species in genus Chaetomorpha Kützing in China. Fisheries Science 28:162-163.

Coppejans E, Leliaert F, Dargent O, Gunasekara K and Clerck O (2009) Srilanka Seaweeds. Methodologies and Field Guide to the Dominant Species". University of Ruhuna, Dept. of Botany, Matora, Srilanka. pp.1-265.

Fu B (2014) Regulation of environmental factors in the process of lipid accumulation of a marine diatom. Doctoral dissertation. Tianjin: Tianjin University of Science \& Technology.

\section{Reference}


Gressler V (2010) Composição química e potencial biológico das algas vermelhas marinhas Laurencia filiformis, Laurencia intricata, Plocamium brasiliense Ochtodes secundiramea da costa brasileira. Tese de doutoramento, Universidade de São Paulo.

Kibria G (2004) Dissolved Oxygen: The Facts. Environmental update-Dissolved Oxygen: The Facts. 162:2-4.

Laungsuwon R, Chulalaksananukul W (2013) Antioxidant and anticancer activities of freshwater green algae, Cladophora glomerata and Microspora floccosa, from Nan River in northern Thailand, Maejo International Journal of Science and Technology 7, 181.

Lee YC, Chang SP (2011) The biosorption of heavy metals from aqueous solution by Spirogyra and Cladophora filamentous macroalgae, Bioresour. Technol., 2011, 102, 5297-5304.

Li J, Wang J, Zhang J (1991) Removal of nutrient salts in relation with algae in ponds. Water Science and Technology, 24(5): 75-83.

Mehrdadi N, Ghobadi M, Nasrabadi T, Hoveidi H (2006) Evaluation of the quality and selfpurification potential of Tajan river using QUAL2E model, Iranian Journal of Environmental Health Science \& Engineering 3 (3): 199-204.

Messyasz B, Leska B, Fabrowska J, Pikosz M, Roj E, Cieslak A, Schroeder G (2015) Biomass of freshwater Cladophora as a raw material for agriculture and the cosmetic industry. Open Chemistry; 13: 1108-1118 DOI: 10.1515/chem2015-0124.

Mountford K (1969) Measuring dissolved oxygen as an indicator of primary productivity. Chesapeake Science, 327-330.

Pulz O, Gross W, (2004) Valuable products from biotechnology of microalgae, Appl. Microbial. Biotechnol. 65: 635-648.

Rao SVR (1986) Int. J. Environ. Studies 27. 219223.

Samudro G and Mangkoedihardjo S (2010) Review on $\mathrm{BOD}, \mathrm{COD}$ and $\mathrm{BOD} / \mathrm{COD}$ ratio: A triangle zone for toxic, biodegradable and stable levels. International Journal of Academic Research.

Sánchez E, Colmenarejo M F, Vicente J, Rubio A, García M G, Travieso L, Borja R (2007) Use of the water quality index and dissolved oxygen deficit as simple indicators of watersheds pollution. Ecological indicators, 7(2): 315-328.

Savithramma N, Rao ML, Rukmini K and Devi PS (2011). Antimicrobial activity of silver nanoparticles synthesized by using medicinal plants. International Journal of Chem Tech Research, Vol 3(3), pp. 1394-1402.

Schortemeyer M, Stamp P and Feil B (1997) Ammonium Tolerance and Carbohydrate Status in Maize Cultivars. Annuals of Botany, 79: 2530.

Selvi Dhanam D, Dhandayuthapani K (2013) Optimization of $\beta$-carotene production by marine microalga-Dunaliella salina. Int $J$ Curr Microbiol Appl Sci; 2: 37-43.

Smith D and Piedrahita R. (1988). The relation between phytoplankton and dissolved oxygen in fish pond. Aquaculture, 68: 249 - 265.

Tsutsui I, Miyoshi T, Aue-Umneoy D, Songphatkaew J, Meeanan C, Klomkling S, Sukchai H, Pinphoo P, Yamaguchi I, Ganmanee M, Meano Y, Hamano K. (2015) High tolerance of Chaetomorpha sp. to salinity and water temperature enables survival and growth in stagnant waters of central Thailand. International Aquatic Research 7(1):47-62 DOI 10.1007/s40071-014-0092-4.

Xu H, Liu ZP, Yuan L, Yang LZ. (2009) Effects of $\mathrm{pH}$ on the growth of several freshwater algae. Environmental Science and Technology 32(1):27-30.

Żbikowski R, Szefer P, Latała A (2007) Comparison of green algae Cladophora sp. and Enteromorpha sp. as potential biomonitors of chemical elements in the southern Baltic, Sci. Total Environ. 387 (2007) 320-332.
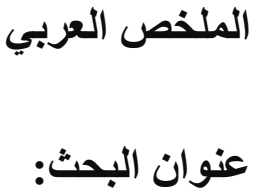

سهام أبو أحمد'، محمد دياب'، رضوى الثنو اني'، ماجدة العدل'

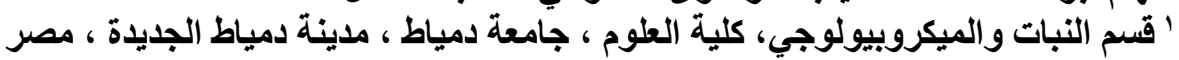

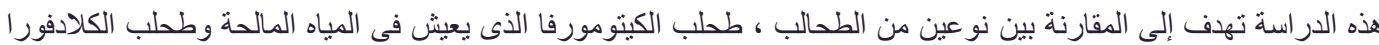

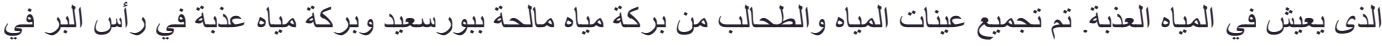


نجد أن النموات العالية للطحلبين و المتكونة نتيجة لتو افر الظروف المناسبة في هذه الأماكن من ظروف بيئية أو الحالة الغذائية

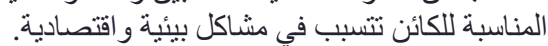
هذه النمو ات العالية من التطحلبين تتسبب في الانتز اع الكامل للأكسجين الذائب في منتصف وقاع سطح المياه في النصف الثاني من يتشبب الفقد في الأكسجين في فقد هائل في بيئة الأحياء المائية . على الرغم أن هذين الطحلبين ينتميان لنفس العائلة إلا أن أنهم

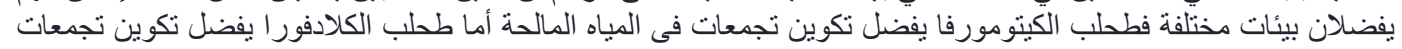
في المياه العذبة.

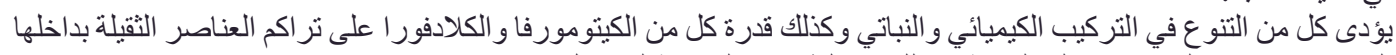

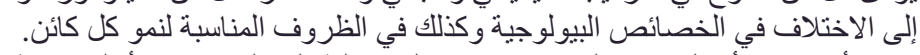

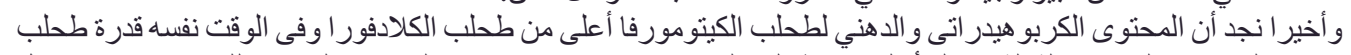

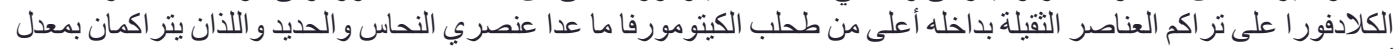
أعلى في طحلب الكيتو مورفا. 